\title{
ANALISA PENGARUH SERAT RAMI DAN FIBERGLASS DENGAN VARIASI BUTIRAN KUNINGAN (Cu-Zn) MESH 40,50,60 TERHADAP NILAI KEKERASAN, KEAUSAN, DAN KOEFISIEN GESEK KAMPAS
}

\section{REM}

\author{
Pramuko Ilmu Purboputro, Bayu Aji Prabowo \\ Teknik Mesin Universitas Muhammadiyah Surakarta \\ Jl. A. Yani Tromol Pos 1 Pabelan, Kartasura \\ Email: bayuajiprabowo45@gmail.com
}

\begin{abstract}
ABSTRAK
Pada penelitian ini peneliti membuat kampas rem sepeda motor dengan menggunakan bahan komposit serat alam dan serat buatan yang ramah lingkungan dengan beberapa variasi komposisi bahan untuk mengetahui nilai kekerasan, keausan, dan koefisien gesek. Bahan-bahan yang digunakan pada penelitian ini yaitu serat rami, fiberglass, serbuk kuningan mesh 40, 50, dan 60, kalsium karbonat, barium sulfat, dan resin polyester dan katalis sebagai matrik nya. Kemudian kampas rem diuji gesek dengan beban $16 \mathrm{~kg}$ selama 3 jam dengan uji kering, air, oli, air garam, dan minyak rem dan kemudian dihitung keausan dan koefisien geseknya, dan diuji kekerasan dengan menggunakan Durometer dengan standar ASTM D2240. Dari hasil pengujian kekerasan didapatkan nilai tertinggi didapatkan pada kampas rem Indopart dengan nilai 86,7 HD, sedangkan kekerasan yang mendekati kampas Indopart didapatkan pada kampas rem variasi mesh 60 dengan nilai kekerasan 84,6 HD. Hasil pengujian keausan menunjukan nilai keausan kampas rem terendah terjadi pada variasi kampas Indopart, sedangkan keausan terendah dibawahnya terjadi pada kampas variasi kuningan mesh 60 dengan nilai $81,25 \mathrm{~mm}^{3} / \mathrm{jam}$ kondisi

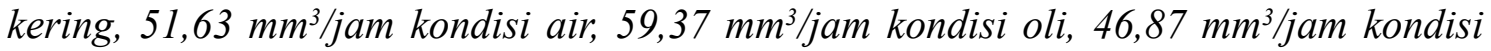
air garam, dan 69,37 mm3/jam pada kondisi minyak rem. Hasil data yang diperoleh nilai koefisien gesek tertinggi didapatkan variasi kampas rem indopart, sedangkan yang mendekati didapatkan kampas rem variasi kuningan mesh 60 dengan nilai 0,6226, 0,5725, 0,5383, 0,5754, dan 5718. Pada foto mikro setelah dilakukan uji gesek kampas mesh 50 mengalami kegagalan bonding kohesive, sedangkan mesh 40 dan 60 mengalami bonding kohesive dan adhesive. Dari pembahasan diatas dapat disimpulkan bahwa besar kecil ukuran serbuk yang digunakan mempengaruhi nilai kekerasan, keausan, dan juga koefisien gesek.
\end{abstract}

Kata kunci: Serbuk Kuningan (Cu-Zn), Serat Rami, Polyester

\section{PENDAHULUAN}

\section{Latar Belakang}

Perkembangan otomotif yang semakin modern membuat permintaan pasar akan produk suku cadang semakin besar. Kampas rem merupakan salah satu komponen dari kendaraan bermotor yang berfungsi untuk menghentikan laju kendaraan bermotor. Rem berfungsi untuk memperlambat atau menghentikan gerakan dari roda sehingga gerak roda menjadi lambat. Energi kinetik yang hilang dari benda yang bergerak ini diubah menjadi panas karena adanya gesekan. Jika rem tidak berfungsi dengan baik, maka dipastikan akan berakhir dengan kecelakaan. Faktor keamanan dari pengendara adalah hal yang sangat penting. Sehingga setiap produsen 
kendaraan bermotor merancang sistem dan menggunakan komponen rem (kampas rem) yang sesuai dengan kemampuan kendaraan. Beredarnya kampas rem jenis asbestos banyak beredar dengan harga yang murah dan menjamin keawetan kampas rem, akan tetapi hasil dari serbuk gesekan yang berupa partikel kecil sangat berbahaya bagi kesehatan manusia.

Pemakaian kampas rem biasanya tidak lebih dari 10000 kali kontak pengereman, artinya penggunaan dalam kota bisa jadi tidak lebih dari 6 bulan, apalagi terjadi keluhan umur yang lebih pendek akibat kampas rem yang ausnya tidak merata, sehingga pengereman tidak efektif.

Kekuatan bahan partikel komposit rem, sangat dipengaruhi besarnya partikel , bahan matriknya, dan proses pembuatannya. Kekuatan partikel komposit diperoleh maksimal pada ukuran 0,01 sampai $0,1 \mathrm{~mm}$ dan kekuatan surface bonding, pengepresan, sintering.Proses tersebut sangat jarang dipaparkan oleh produsen kampas rem, sehingga perlu adanya penelitian tentang bahan dan proses yang standar secara ilmiah agar kampas rem mudah dibuat di negara kita sendiri, sehingga sangat perlu dilakukannya penelitian ini dengan secara terus menerus dengan harapan bisa mendapatkan komposisi yang lebih baik dan kinerja yang lebih baik dibandingkan dengan kampas rem yang ada di pasaran, atau setidaknya bisa mendekati dan bisa bersaing.

Komposisi bahan pembuatan kampas rem sangat berpengaruh akan kinerja kampas rem itu sendiri. Secara umum zat penyusun didalam bahan fraksi terdiri dari serat, bahan pengisi, dan bahan pengikat. Serat berfungsi untuk meningkatkan koefisien gesek dan kekuatan mekanik bahan. Serat sendiri terdiri dari serat alam dan serat buatan. Serat alam yang sering dipakai biasanya dari tumbuhan kelapa, bambu, rami, dan lain sebagainya. Sedangkan serat buatan sendiri misalnya nilon dan serat gelas. Sedangkan bahan-bahan pendukung lainnya seperti $\mathrm{CaCO}_{3}$ (Kalsium Karbonat), $\mathrm{BaSO}_{4}$ (Barium Sulfat), serta serbuk logam seperti serbuk kuningan dan alumunium.

\section{Perumusan Masalah}

Masalah dalam penelitian ini adalah untuk menentukan sifat-sifat mekanisme terutama ketangguhan material terhadap beban. Berdasarkan hal tersebut dapat dirumuskan sebagai berikut:

1. Bagaimana pengaruh Serat Rami dan Fiberglass dengan variasi butiran mesh logam Kuningan $(\mathrm{Cu}-\mathrm{Zn})$ terhadap tingkat kekerasan kampas rem.

2. Bagaimana pengaruh Serat Rami dan Fiberglass dengan variasi butiran mesh logam Kuningan $(\mathrm{Cu}-\mathrm{Zn})$ terhadap nilai keausan kampas rem.

3. Bagaimana pengaruh Serat Rami dan Fiberglass dengan variasi butiran mesh logam Kuningan $(\mathrm{Cu}-\mathrm{Zn})$ terhadap koefisien gesek kampas rem.

\section{Tujuan Penelitian}

Berdasarkan latar belakang yang telah diuraikan, maka penelitian ini bertujuan untuk:

1. Mengetahui kualitas kekerasan pada kampas rem dengan menggunakan Serat Rami dan Fiberglass dengan variasi butiran mesh logam Kuningan dengan matrik Polyester Resin.

2. Mengetahui nilai keausan pada kampas rem dengan menggunakan Serat Rami dan Fiberglass dengan variasi butiran mesh logam Kuningan dengan matrik Polyester Resin.

3. Mengetahui nilai koefisien gesek pada kampas rem dengan menggunakan Serat Rami dan Fiberglass dengan variasi butiran mesh logam Kuningan dengan matrik Polyester Resin.

\section{Batasan Masalah}

Supaya permasalahan yang dibahas tidak melebar maka perlu diadakan pembatasan masalah sebagai berikut: 
1. Bahan

Pada penelitian ini bahan yang digunakan yaitu serat rami, seret fiberglass, serbuk kuningan, barium sulfat $\left(\mathrm{BasO}_{4}\right)$, Calcium Carbonat $\left(\mathrm{CaCO}_{3}\right)$, Epoxy Resin, dan Polyester Resin beserta Katalis.

2. Pengujian

Penelitian ini menggunakan alat uji kekerasan durometer dengan standar ASTM D2240, pengujian gesek dengan mengacu standar SNI 09-2663-1992, dan pengujian foto mikro.

\section{TINJAUAN PUSTAKA DAN DASAR TEORI}

\section{Tinjauan Pustaka}

Kampas rem berbahan bahan asbestos hanya mampu bertahan pada suhu $200^{\circ} \mathrm{C}$ dan debu dari kampas rem ini sangat beracun yang dapat menyebabkan penebalan dan luka gores pada paru-paru apabila kampas ini terkena air maka daya pengeremannya akan terganggu, berbeda dengan kampas rem berbahan non asbestos yang mampu bertahan hingga suhu $300^{\circ} \mathrm{C}$ dan kampas rem berbahan non asbes tidak menghasilkan debu beracun sehingga ramah lingkungan dan apabila terkena air daya pengeremannya masih tetap optimal (Desi Kiswiranti, 2007)

Menurut Khoirul (2017) dari hasil keausan rata-rata pada pengujian pengaruh kering, air, dan oli bahwa kampas rem tembaga dengan variasi mesh 50,60,80, dan 100. Menunjukan bahwa mesh 100 lebih rendah dibandingkan dengan kampas rem variasi lainnya yaitu sebesar 49,7576 $\mathrm{mm}^{3} / \mathrm{jam}, 60,1238 \mathrm{~mm}^{3} / \mathrm{jam}$, dan $60,0783 \mathrm{~mm}^{3} / \mathrm{jam}$ pada uji gesek selama $3 \mathrm{jam}$. Koefisien gesek pada pengujian pengaruh kering kampas rem variasi tembaga mesh 100 paling tinggi. Pada uji gesek selama 3 jam yaitu sebesar 0,8857 , sedangkan pada pengujian gesek pengaruh air kampas variasi 60 memiliki koefisien gesek paling tinggi sebesar 0,8297 , pada pengujian pengaruh oli kampas rem variasi tembaga mesh 70 memiliki koefisien gesek paling tinggi yaitu sebesar 0,8863. Nilai kekerasan kampas rem variasi tembaga mesh 100 lebih baik dibandingkan dengan variasi mesh lainnya yaitu sebesar 87,83 ShoreD.

Yudha Ardhi (2018) melakukan penelitian tentang kampas rem dengan menggunakan serat rami variasi 1,5 gram, 2,5 gram, dan 3,5 gram. Dari hasil yang didapatkan, nilai kekerasan tertinggi terjadi pada kampas rem variasi 3,5 gram serat rami. Sedangkan hasil keausan terbaik didapatkan pada serat rami variasi 1,5 gram serta nilai koefisien gesek terbaik juga didapatkan kampas rem variasi serat rami 1,5 gram.

\section{Dasar Teori}

\section{Kekerasan}

Kekerasan adalah daya tahan bahan terhadap goresan atau penetrasi permukaannya. Definisi yang lain adalah ukuran ketahanan bahan terhadap defeormasi plastis. Tiga jenis umum mengenai ukuran kekerasan yang tergantung cara pengujian yaitu kekerasan goresan, kekerasan lekukan, dan kekerasan pantulan atau kekerasan dinamik, untuk kekerasan kampas rem ini menggunakan durometer shore $\mathrm{D}$

\section{Keausan}

Keausan umumnya didefinisikan sebagai kehilangan material secara progresif atau pemindahan sejumlah material dari suatu permukaan sebagai suatu hasil pergerakan relatif antara permukaan tersebut dan permukaan lainnya. Pembahasan mekanisme keausan pada material berhubungan erat dengan gesekan dan pelumasan. Keausan bukan merupakan sifat dasar material, melainkan respon material terhadap terhadap sistem luar (kontak permukaan). Material apapun dapat mengalami keausan disebabkan mekanisme yang beragam. Berikut menghitung nilai keausan 


\section{Diagram Alir Penelitian}

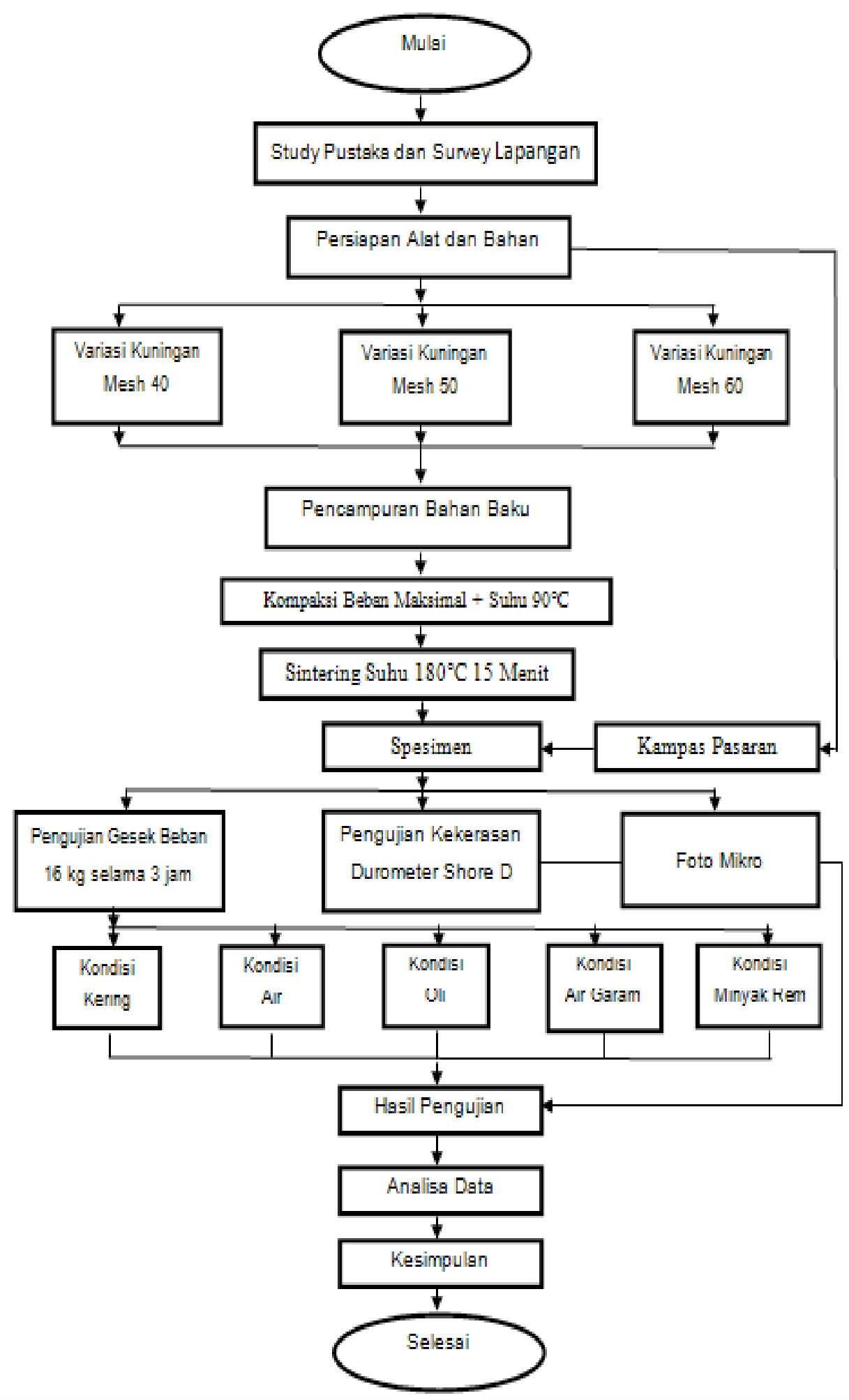

Gambar 1 Diagram Alir Penelitian 


\section{HASIL PENELITIAN}

Hasil Pengujian Kekerasan yang Mengacu pada Standar ASTM D2240

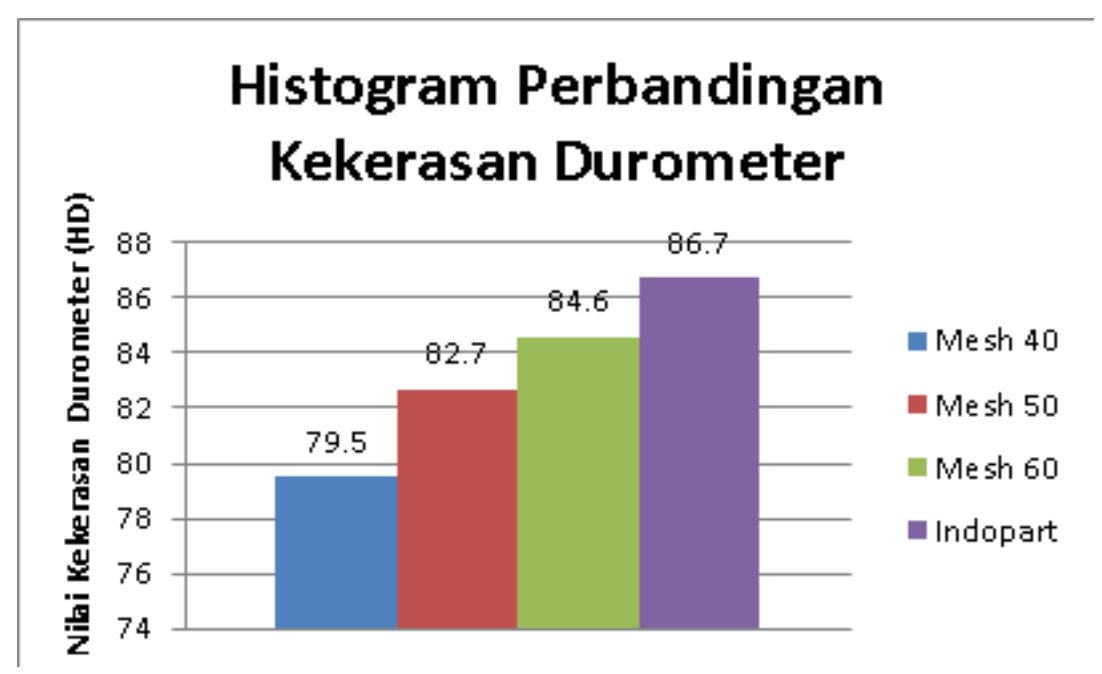

Gambar 2 Grafik Perbedaan Nilai Kekerasan Kampas Setelah di Oven

Hasil pengujian kekerasan didapatkan nilai tertinggi pada kampas indopart sedangkan kekerasan kampas rem yang mendekati kampas rem indopart ditunjukan pada kampas mesh 60, hal ini dikarenakan butiran serbuk lebih halus dibanding mesh 50 dan mesh 40 sehingga membuat permukaan kampas rem menjadi lebih rapat.

\section{Hasil Pengujian Gesek}

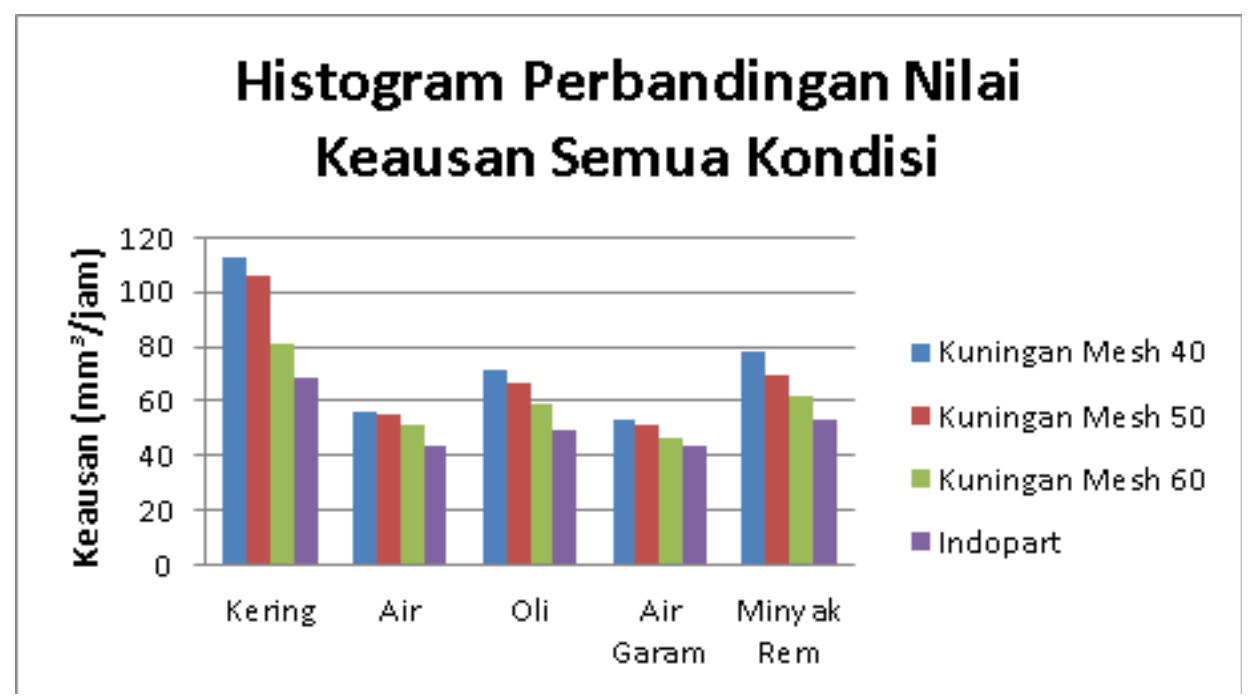

Gambar 3. Grafik Hubungan Antara Jenis Kampas Rem dengan Pengaruh Kondisi PengujianKeausan Rata-Rata. 


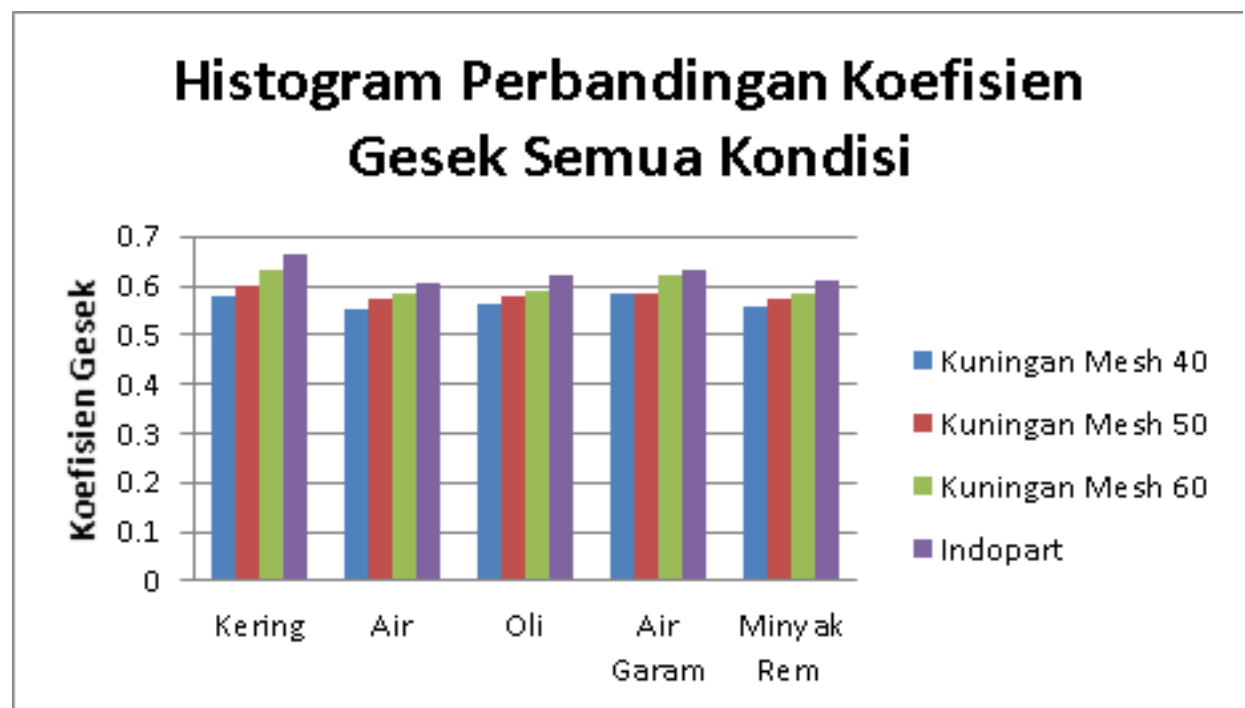

Gambar 4. Grafik Perbandingan Koefisien Gesek Semua Jenis Kampas Rem Pada Pengaruh Pengujian Semua Kondisi

Pengujian Foto Mikro Sebelum Uji Gesek

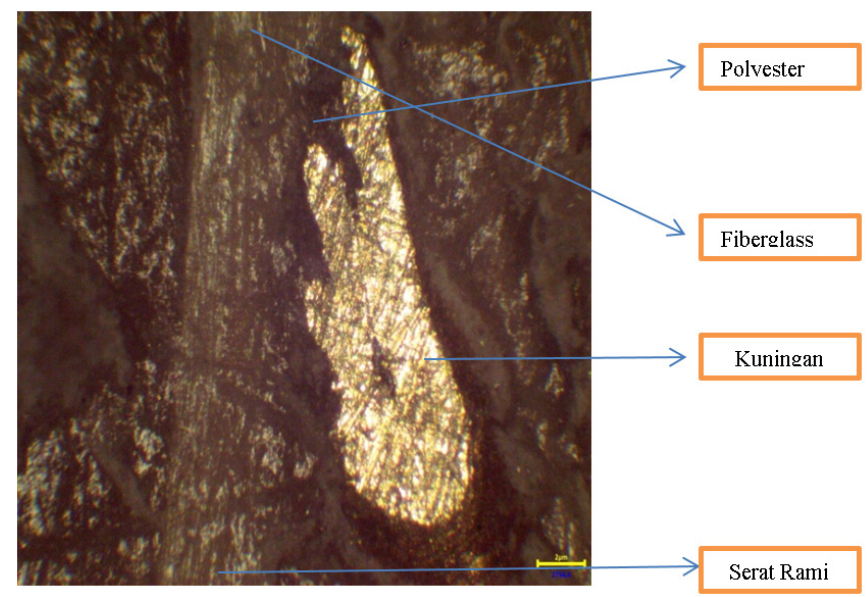

Gambar 5 Foto Mikro Mesh 40 Sebelum Uji Gesek

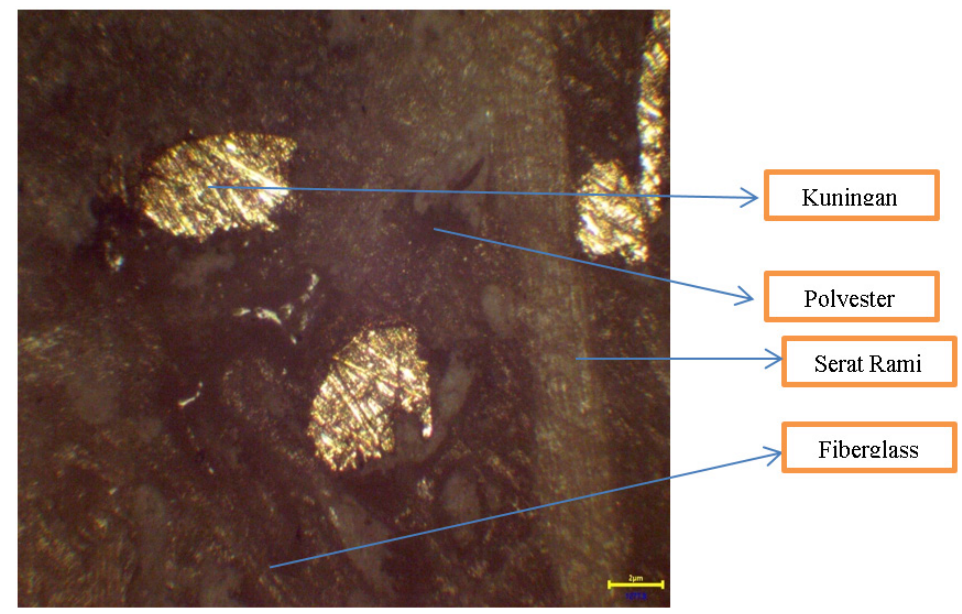

Gambar 6 Foto Mikro Mesh 50 Sebelum Uji Gesek 


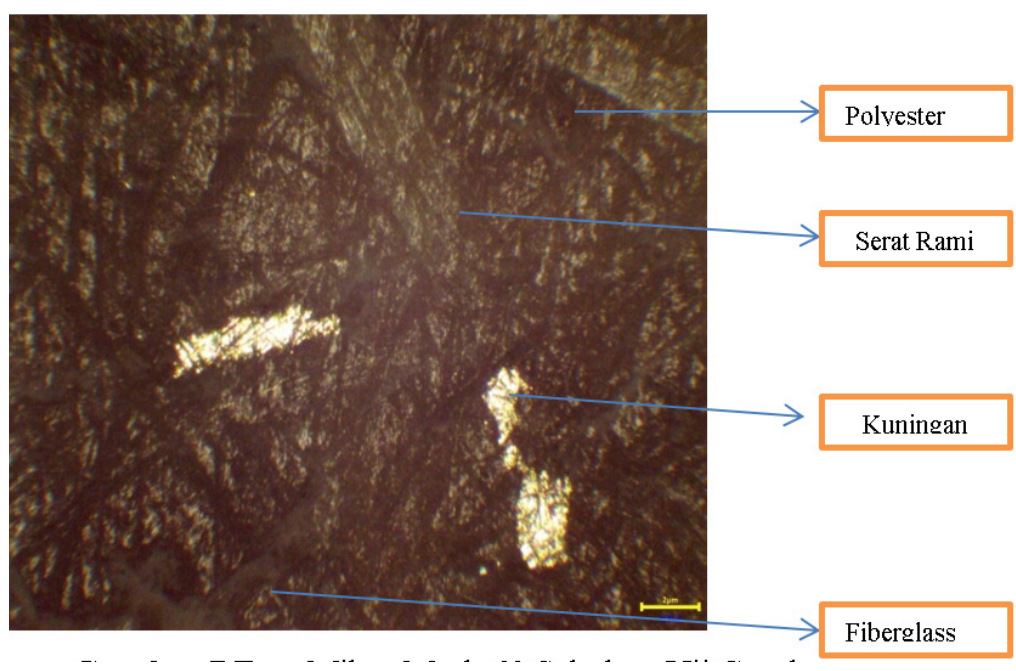

Gambar 7 Foto Mikro Mesh 60 Sebelum Uji Gesek

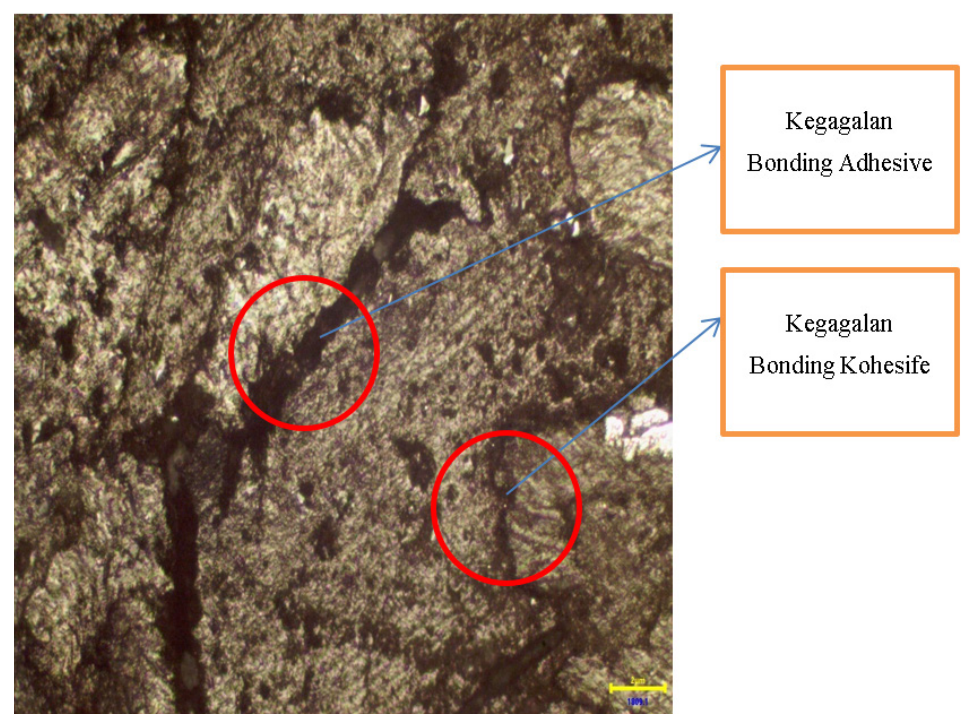

Gambar 8 Foto Mikro Mesh 40 Sesudah Uji Gesek

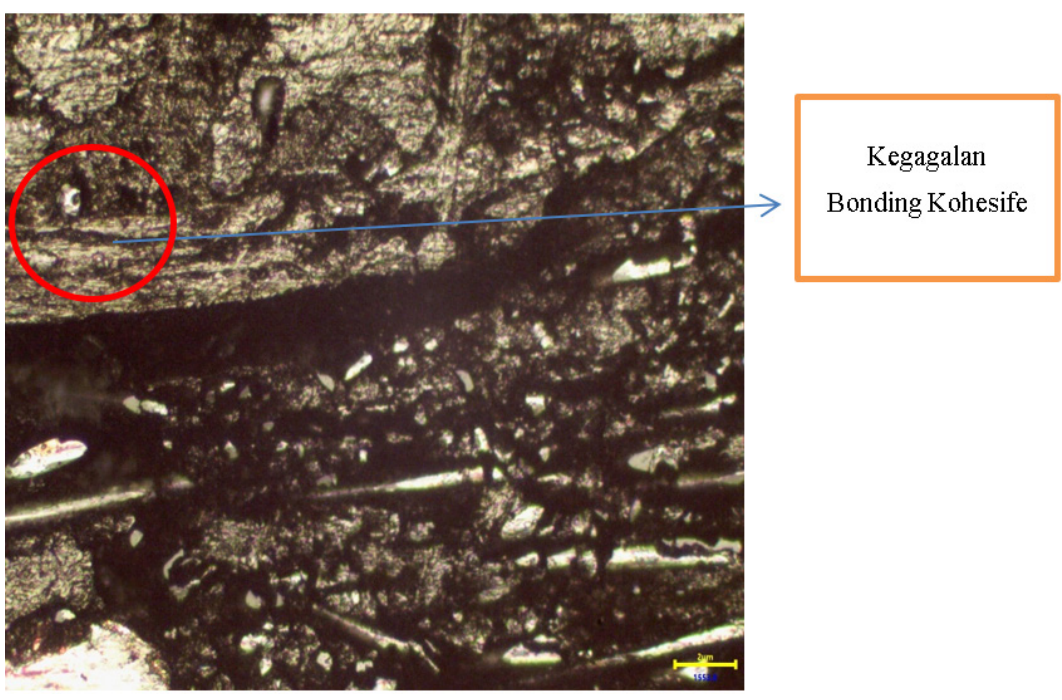

Gambar 9 Foto Mikro Mesh 50 Sesudah Uji Gesek 


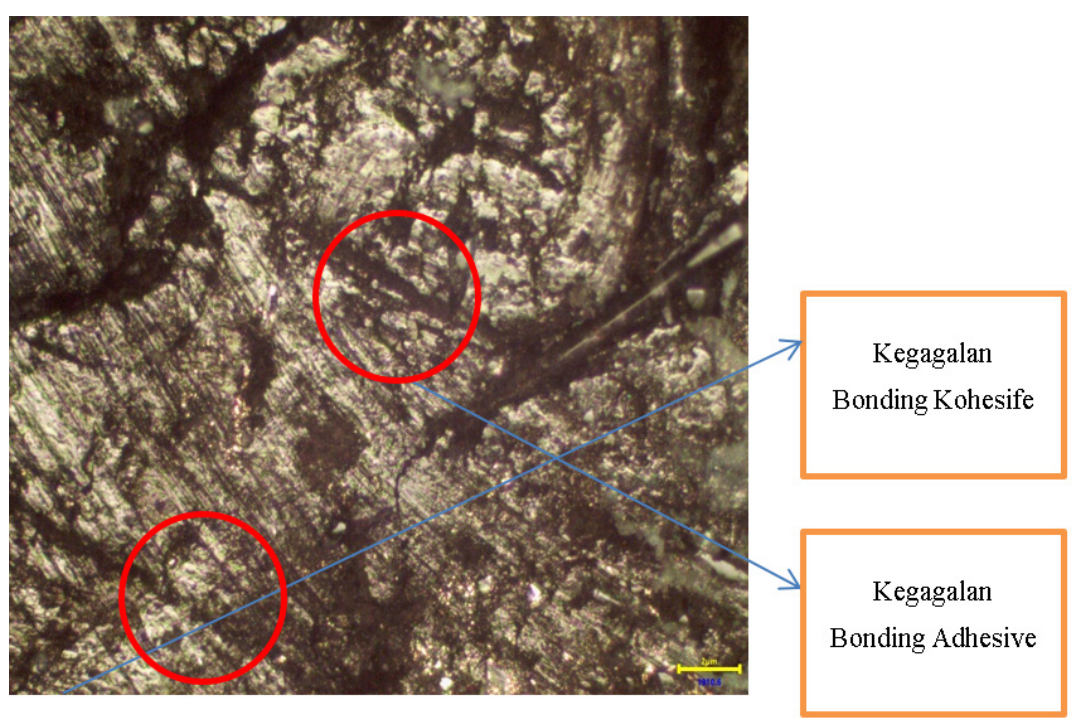

\section{Kesimpulan}

Gambar 10 Foto Mikro Mesh 60 Sesudah Uji Gese

1. Hasil pengujian kekerasan dengan menggunakan alat Durometer Shore D menunjukan bahwa kekerasan mendapatkan nilai 84,6 HD untuk mesh 60, 82,7 HD untuk mesh 50, dan 79,5 HD untuk mesh 40. Dari data yang diperoleh bisa dianalisis bahwa nilai kekerasan kampas rem variasi mesh 60 dengan nilai 84,6 HD mendekati nilai kekerasan kampas rem Indopart dengan nilai kekerasan 86,7 HD. Dengan demikian dapat diambil kesimpulan bahwa besar kecilnya ukuran serbuk material pembuatan kampas rem akan mempengaruhi tingkat kekerasannya.

2. Hasil pengujian keausan menunjukan perbandingan keausan rata-rata semua jenis kampas rem pada semua kondisi, diketahui bahwa nilai keausan terendah terjadi pada variasi kampas indopart dikarenakan memiliki tingkat kekerasan yang tinggi dan juga struktur permukaan yang rapat, sedangkan keausan terendah dibawahnya terjadi pada kampas variasi kuningan mesh 60 dengan menunjukan nilai $81,25 \mathrm{~mm}^{3} / \mathrm{jam}$ pada kondisi kering, $51,63 \mathrm{~mm}^{3} / \mathrm{jam}$ kondisi air, $58,75 \mathrm{~mm}^{3} / \mathrm{jam}$ kondisi oli, $46,87 \mathrm{~mm}^{3} /$ jam kondisi air garam, dan $61,88 \mathrm{~mm}^{3} /$ jam. Berbeda dengan kampas variasi mesh 40, dan mesh 50 yang lebih besar nilai nilai keausannya. Hal ini dikarenakan kecilnya butiran kuningan yang digunakan sehingga berdampak pada besar kecilnya nilai keausan.

3. Hasil data yang diperoleh nilai koefisien gesek tertinggi didapatkan kampas rem variasi Indopart, sedangkan nilai yang mendekati kampas rem Indopart terjadi pada variasi kuningan mesh 60 pada kondisi pengujian kering dengan nilai 0,6302, pengujian air 0,5868 , pengujian oli 0,5904 , pengujian air garam 0,6193 , dan pengujian minyak rem sebesar 0,5862 . Sehingga dengan ukuran butir yang kecil maka dapat meningkatkan nilai koefisien gesek. Hasil ini dipengaruhi oleh nilai torsi, semakin besar nilai torsi maka nilai koefisien gesek yang didapatkan juga semakin besar.

\section{DAFTAR PUSTAKA}

\section{ASTM D2240-Durometer Hardness}

Desi Ki,2007. Pemanfaatan Serbuk Tempurung Kelapa Sebagai Alternatif Serat Penguat Bahan Friksi Non-Asbes Pada Pembuatan Kampas Rem Sepeda Motor. Laporan Tugas Akhir Jurusan Fisika, Fakultas Matematika dan Ilmu Pengetahuan Alam Universitas Negeri Semarang. 
Khoirul,2017. Pengaruh Ukuran Butir Tembaga (Cu) Terhadap Nilai Kekerasan, Keausan, dan Koefisien Gesek Kampas Rem. Universitas Muhammadiyah Surakarta.

Yudha Hartha, (2017). Pengaruh Serat Rami Dengan Variasi 1,5 gram, 2,5 gram, 3,5 gram Terhadap Nilai Kekerasan, Keausan, dan Koefisien Gesek Kampas Rem. Universitas Muhammadiyah Surakarta

German, R.M.,1984. Powder Metallurgi Science. Metal Powder Federation.

Gibson, R.F.,1994. Principle Of Composite Material Mechanic. McGraw-Hill International Book Company, New York.

Smith, William F.(1990). Principles Of Material Science and Engineering. Second Edition. Mc.Graw Hill Publishing Company

Stolk, Kros. 1994. Elemen Konstruksi Bangunan Mesin, Elemen Mesin. Erlangga. Jakarta

Van Vliet,G.L.J, dan Both.,W.,1984. Teknologi Untuk Bangunan Mesin, Bahan-Bahan 1, Pradnya Paramita, Jakarta. 